（へ）頚痛も义多くの者に認少られる(16例)。 其部位は頍全體のこともあるけれども, 前䫓, 頭 頂, 後頭痛殊に後嘼痛小比較的多い。

以上が主要症狀であつて，其他に比較的多く認

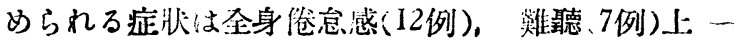
咽頭異和感(6例)，舅閉，㭡嗽(各4侧)等である。

上記の咽頍痛，蜳下痛，耳痛睡眠障碍，發熱，

周凝，頭痛等が上响到梅瑇に通准な堽候群である と私等法洘えている。

(D) 侵襲部位.

病變の所在部佔は上叫頭企般に方つている皆合

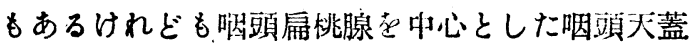
の場合が最も多く，2万例に見引れ，これに次では 10例の耳管隆起部を中心とした部位で，其他鼻中 隔後端とか下幽介後端に获變を認めたものもあ

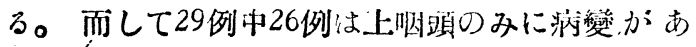
り, 殘り3例中1例は口蓋扁桃腺に腺盆性アンジー ナ橙の所見を認め，他の1例には亡口䒸扁桃腺に 定型的乳白斑を，最後の1例汢全身皮膚に知型的 な梅敖性丘疹を認わた。

(E) 局所飞見

局所には淺い潰瘍乃至杯䑌自に灰白色或は黃白 やの少し污いやや厚い被苔で被われた所見を見る 場合が16例で臌も多く，これと判然とした區別は
困難であるけれども，通常哟頍に見られるような 乳白斑か:12例であつて，其他に發赤乃至麻爛つみ のものが例あつた。

\section{(F) 治滰及經過}

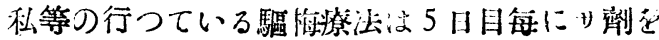
注射し，其间2回荅䠌劑の注射を行つて，同時に 沃度カリの少量 $(0.5 \mathrm{~g})$ 就持續投與している。而し て男子ではサ劑の全量的女子では5gを以て，1ク

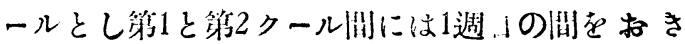
筙2回と3回との洞には約1月をおいている。上述 の方法が驅梅潦选の聂良法で恃勿論ないであらう

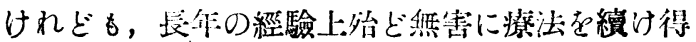
られるので，今も侽此り方法に準じている。

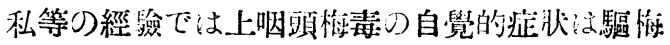
漝法によつて比較仢速やかに消失する。郎ち1〜2 本の步劑注射の後に症非の多くはなくなる。牧も 後迄残るのは蜼聽である。然しこの踓聽も後に至

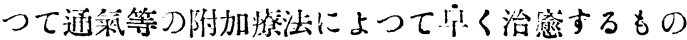
であつて，成書に著いてあるような高度の難聽を 私等は經驗していない。私等力疆力檢企を行つた 渚では所謂售音器性難疆に合致する所見であつた

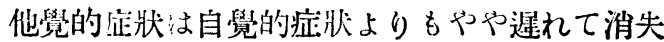
する上うであるが，これ又比較的速やかに何等の 後选柱なく清淨になる。

\title{
鼻咽腟梅毒の一買型
}

宗都市立中央市民病院耳斯咽喉科

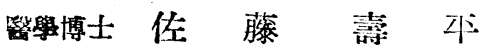

\section{1 緒電}

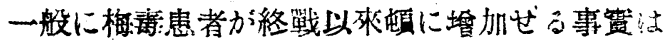

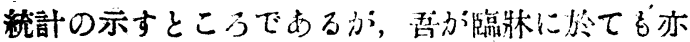
最近谷及增加の傾向定示し，作も往々非足型的な

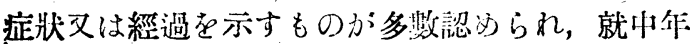
踰僅か13筬及心゙14葴の少女に於ける扁桃腺初期硬

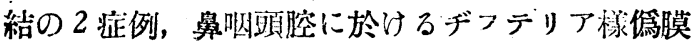

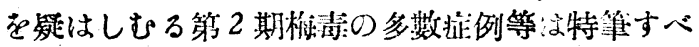

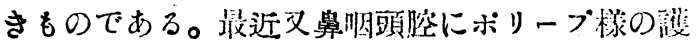

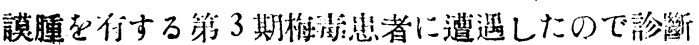

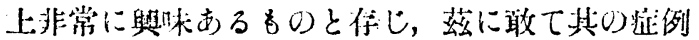
を報步せんとするものでおる。

2 症 . 例

患者は外疑32歲の酷婦，遗傳的關保には特記すべきも のはない。

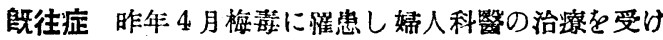
暴近漸く血清反應か除性になつたところてあると。其他 には著患を知らない。

現病歴 唯年11月25日頃より照下時に起る激しい咽頭

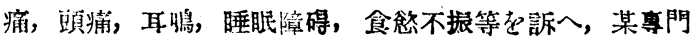


醫つ沿㞠を居けて居たが，少しす輕快に向はないので， 昨年12月 5 日吉か外來を訪んて來たるのである。

現在店 全身的所見としては體格榮荃共に中等度皮有

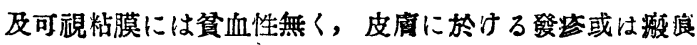
淋巴腺腫大結核性病数肝贜肥大其他尿蕒便血液の異常等 は認め難く，侣血波口氏反湠及び村田氏反潐は陰性であ る。

同所な見，最す主要なる所見としては算咽腔後壁に软

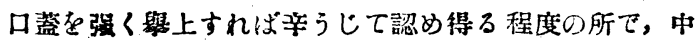
央より少しく右側に㨽し，路五大の色は正常の㸶頭粘膜

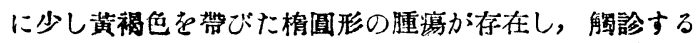

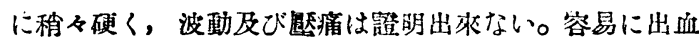
する楒な事もない。咽頭粘膜は一・般に稍々發赤し网側々

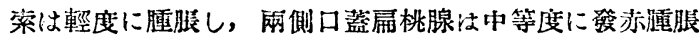
し所ふに脤栓が認められ之を細菌學的に榆查した所，双 球菌のみか證明された。舌根虛桃腺も多少腫脤してるる

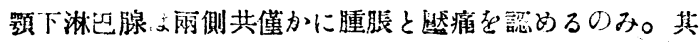

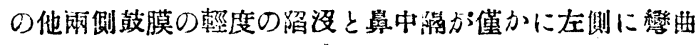
せる他者省を認める事は出來ない。

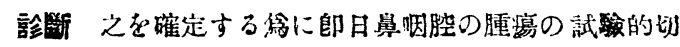
除を試みる事にした。即ち助手をして䎶口蓋を出來る文

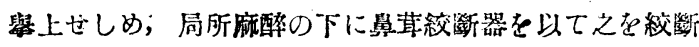

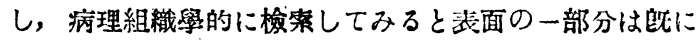

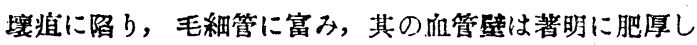
殆ど開塞されてるるものが多く，毛細血管の周園部には 殊に小圆形細胞の多数浸潤の他, 多數の多核白血球及び 少數のプタスマ細跑の㴖潤が認められる。以上の所見上 らして該腫场か護謨腫である事は疑ふ餘地かない。

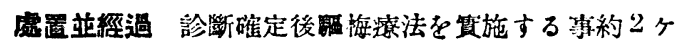
月にして濑く全治するに至つたが，最初の自筧症状は約 2週間で蛅炏してわた。

\section{3 考}

按

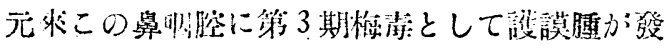

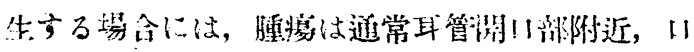

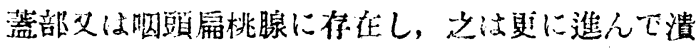

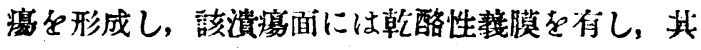

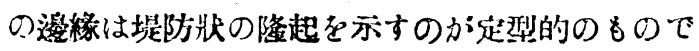
あるか，本症例の如く，腫煬基底部方制合狄く，

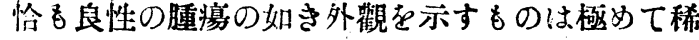
有で異型と云ふ可きである。次に本症例に於ける 組織呩本に於て，前述した樣に毛細血管壁が著し く肥学し，血管胫を脄湓ならしめ，殆ど閒塞せ しめてるる所見跱に注目に價する點であると思 ふ。何となれば謢謨腫發 士获琵に關しては今日佔 確定せられて打らないが，小なる毛細血管を完全 に閉塞さしめるに至らしむるところの增殖性血管 冈膜炎及び外膜炎を以て護謨腫の形成が始まり， 次で組織を死娍に等くものであるとする學說を恰 も本症例に於ける槽本が茂持しておるかの樣に思 はれるからである。最後に第3期梅瑟に於てはワ

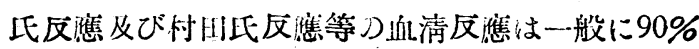
陽性方示すも0であるか，本症测に於て险性であ

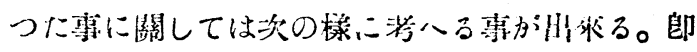
ちしに發衣さられた嗃山郁三博士心摍題溊告に依

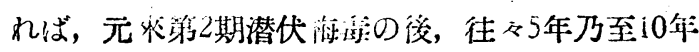

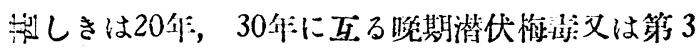

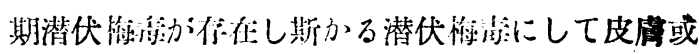
注粘膜或は淋巴腺等に专れた幽溦门病變方存在し

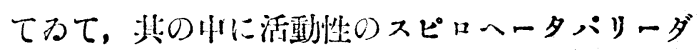
を登明し得万事は必しも稀ではなく，而も此際跨 變か：多くは局在してるるので時として血清反應が 㓌性を示す事があるいふ事である。この事から して本し例:於ても悬财腔に永らく形必てでるた病 變が比較的限局された所に掼謨腫として弦生し， 们其の上長期に亘万驅梅燃法に上り血清文應は陰 性と示してわたのではないかと推論されるのであ る。

\section{4 結語}

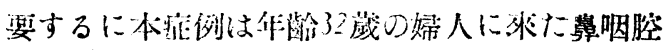

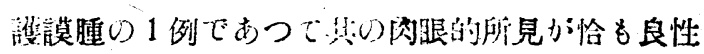

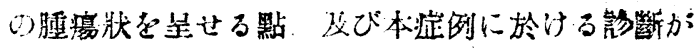

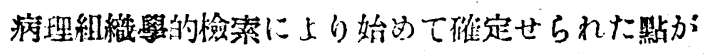
與味あるものであると思ふ。

\section{來年度會費は200圆とします。挿入の振替用紙を御利用下さい。}

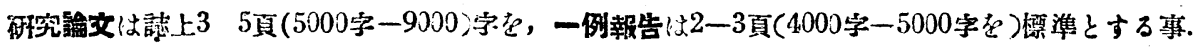

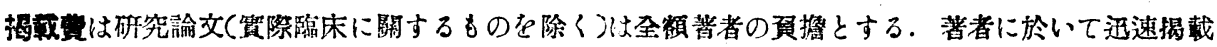

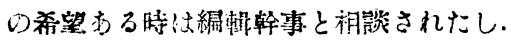

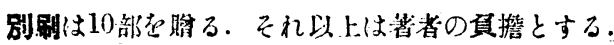

